\title{
KAJIAN PEMANFAATAN SEKAM PADI YANG DIFERMENTASI EFFECTIVE MICROORGANISM-4 (EM-4) DISUPLEMENTASI DAUN SIRIH (Piper betle L) TERHADAP PERFORMANS DAN KARKAS ITIK BALI UMUR 22 MINGGU
}

\author{
PARTAMA, I. B. G., T. G. BELAWA YADNYA, A. A. A. S. TRISNADEWI, \\ A. A. P. P. WIBAWA, DAN I M. MUDITA \\ Fakultas Peternakan, Universitas Udayana, Denpasar - Bali \\ e-mail: idabagusgaga@gmail.com
}

\begin{abstract}
ABSTRAK
Penelitian bertujuan untuk mengetahui pengaruh pemanfaatan sekam padi difermentasi larutan Effective Microorganism-4 (EM-4) dalam ransum disuplementasi daun sirih (Piper betle L.) terhadap performans dan karkas itik bali betina, umur 22 minggu. Penelitian menggunakan rancangan acak lengkap dengan lima perlakuan yaitu ransum tanpa sekam padi (A), ransum mengandung 12,50\% sekam padi (B), ransum mengandung 12,50 \% sekam padi difermentasi EM-4 (C), ransum mengandung 12,50\% sekam padi dan daun sirih (D), serta ransum 12,50\% sekam padi difermentasi EM-4 dan daun sirih (E). Setiap perlakuan terdiri atas empat ulangan dan setiap ulangan berisi lima ekor ituik bali betina, Variabel yang diamati konsumsi ransum, konsumsi antioksidan ransum, bobot badan akhir, pertambahan bobot badan, feed conversion ratio dan karkas meliputi bobot potong, bobot karkas dan persentase karkas. Hasil penelitian menunjukkan bahwa pemberian 12,50 \% sekam padi difermentasi EM-4 serta disuplementasi daun sirih tidak berpengaruh terhadap konsumsi ransum( $\mathrm{P}>0,05)$, namun dapat menghasilkan bobot badan akhir, pertambahan bobot badan lebih tinggi $(\mathrm{P}<0,05)$, serta FCR yang lebih rendah $(\mathrm{P}<0,05)$ serta bobot karkas dan persentase karkas yang lebih baik daripada perlakuan yang lainnya. Dapat disimpulkan bahwa pemberian sekam padi yang difermentasi EM-4 serta disuplementasi daun sirih dapat memperbaiki performans dan karkas yang lebih baik daripada perlakuan yang lainnya.
\end{abstract}

Kata kunci: effective microorganisms-4, daun sirih, performans, karkas, itik bali

\section{THE UTILIZATION OF EFFECTIVE MICROORGANISM-4 FERMENTED RICE HULL IN DIETS AND Piper beetle LEAF MEAL SUPPLEMENTED ON PERFORMANCE AND CARCASS OF 22 WEEKS MALE BALI DUCK}

\begin{abstract}
An experiment was carried out to study the effect of the utilization effective microorganisms-4 (EM-4) fermented rice hull in diets and Piper betle L. supplemented on the performans and carcass of male bali duck old 22 weeks. The experiment design used is completely randomized design with five treatments: control treatment (A), diets containing $12.50 \%$ rice hull (B), diets containing 12.50\% fermented EM-4 rice hull (C), diets containing $12.50 \%$ rice hull and Piper beetle leaf (D), diets containing 12.50\% fermented rice hull and Piper betle leaf (E). Each treatment consisted five bali ducks and each treatment was replicated four times. Variables observed were feed consumption, feed antioxidant consumption, final body weight, body weight gain, feed conversion ratio and carcass included slaughter weight, carcass weight, and carcass percentage. The results showed that offered diets containing $12.50 \%$ fermented effective microorganisms-4 (EM-4 rice hull in diets not affected of feed consumption $(\mathrm{P}>0,05)$, but increase $(\mathrm{P}<0.05)$ final body weight, body weight gain were than treatment $\mathrm{A}$, and treatment $\mathrm{E}$ increase on carcass weight, carcass persentage and improve FCR $(\mathrm{P}<0.05)$ compared with other treatments. It was concluded that offered fermented rice hull with effective microorganisms-4 and Piper betle L. supplemented can improve the performance and carcass of male bali duck old 22 weeks.
\end{abstract}

Key words : effective microorganisms-4, Piper betle L., performances, carcass, bali duck 


\section{PENDAHULUAN}

Sekam padi merupakan hasil sampingan daripada penggilingan padi yang hasil utamanya adalah beras. Hasil sampingan (sekam padi ) yang dihasilkan cukup berlimpah karena beras merupakan makanan pokok masyarakat Indonesia. Sekam padi sebagai bahan pakan allternatif mempunyai kandungan zat nutrisi adalah $12,5 \%$ air, 3,1\% protein kasar, 29,2\% bahan ekstrak tiada nitrogen (BETN), serat kasar 35\%, 2,7\% lemak, dan 17,5\% abu dengan kecernaan yang rendah (Lubis, 1992) dan akan berpengaruh terhadap efisiensi penggunaan ransum, maka perlu difermentasi, agar nilai nutrisinya bisa diperbaiki (Widyanto, 1995). Salah satu inokulan yang baik digunakan mencerna bahan ransum yang tinggi serat kasar adalah larutan Effective Microorganisms-4 (EM-4) (Higa dan Wididana,1993). Di dalam larutan EM-4 mengandung hampir 98\% enzim selulolitik yang dapat menghidrolisa selulosa menjadi senyawa karbohidrat yang lebih sederhana yaitu glukosa. Yadnya et al. (2007) melaporkan bahwa fermentasi serbuk gergaji kayu dengan larutan EM-4 dan amoniasi urea dapat meningkatkan nilai nutrisi serbuk gergaji kayu dengan data sebagai berikut: terjadi penurunan kadar serat kasar dari 81,91\% menjadi 48,40\%, dan peningkatan kadar protein kasar dari 0,90\% menjadi 8,10\%, lemak kasar dari 0,32\% menjadi 2,30\%, sedangkan bagaimana pengaruh amoniasi dan biofermentasi larutan EM-4 terhadap nilai nutrisi terhadap nilai nutrisi sekam padi belum diketahui secara pasti, maka dari itu perlu dicoba dalam penelitian, terutama untuk penelitian pada ternak unggas diataranya adalah ternak itik.

Ternak itik adalah ternak unggas yang sangat mudah beradaptasi dengan lingkungannya, namun produktivitas itik bali relatif masih rendah, maka dari itu perlu diberikan yang cukup bergizi sesuai dengan kebutuhannya (Matram, 1984). Mengingat biaya ransum dalam usaha peternakan relatif tinggi berkisar $60-70 \%$ (Nitis, 1980). Untuk itulah perlu memanfaatkan sekam padi terfermentasi sehingga efisiensi dapat ditingkatkan. Agar produktivitas ternak itik lebih baik disuplementasi dengan bahan ransum yang mengandung zat antioksidan. Salah satu diantaranya adalah daun sirih (Piper betle L). Surya et al. (2008) melaporkan bahwa daun sirih (Piper betle L.) mempunyai total fenol dan aktivitas antioksidan cukup tinggi yaitu $1070 \mathrm{mg} / 100 \mathrm{ml}$ dan 97,44\% daripada kandungan total fenol dan aktivitas antioksidan daun mengkudu hanya 33,236\% dan 27,73 \%..Susila et al (2017) melaporkan pemberian sekam padi terfermentasi yang disuplementasi daun ubi jalar ungu dapat memperbaiki penampilan itik bali fase pertumbuhan. Pemberian sekam padi terfermentasi Aspergillus niger yang disuplementasi daun ubi jalar ungu (Ipomoea batatas L) dapat memperbaiki bobot potong dan bobot karkas pada itik bali (Budiarta, 2017).

Berdasarkan ihal tersebut maka perlu dikaji pemanfatan sekam padi terfermentasi Effective Microorgnism-4 (EM-4) yang disuplementasi daun sirih (Piper betle L.) terhadap efisiensi penggunaan ransum dan karkas itik bali umur 22 minggu.

\section{MATERI DAN METODE}

\section{Tempat dan Lama Penelitian .}

Penelitian mengkaji pemanfatan sekam padi terfermentasi Effective Microorgnism-4 (EM-4) yang disuplementasi daun sirih (Piper betle L.) terhadap efisiensi penggunaan ransum dan karkas itik bali umur 22 minggu selama 10 minggu. Penelitian dilaksanakan di Desa Guwang, Kecamatan Sukawati, Kabupaten Gianyar, Provinsi Bali. Analisis kandungan antioksidan ransum dilaksanakan di Laboratorium Kimia dan Mikroorganisme, Fakultas Teknologi Pertanian, Universitas Udayana selama 2 minggu. Analisis karkas dilaksanakan di Laboratorium Teknologi Hasil Ternak, Fakultas Peternakan, Universitas Udayana selama 4 minggu.

\section{Itik}

Itik yang digunakan dalam penelitian adalah itik bali umur 12 minggu yang diperoleh dari pengepul itik yang berasal dari Desa Guwang, Kecamatan Sukawati, Kabupaten Gianyar sebanyak 125 ekor dengan kisaran bobot badan awal 0,983 $\pm 7,07 \mathrm{~g}$

\section{Kandang dan perlengkapannya}

Penelitian menggunakan kandang sistem battery colony berlantai dua sebanyak 21 petak. setiap petak kandang mempunyai ukuran panjang $70 \mathrm{~cm}$, lebar $70 \mathrm{~cm}$, dan tinggi $70 \mathrm{~cm}$. Kandang dilengkapi dengan tempat pakan dan tempat minum yang terbuat dari bilah-bilah bambu yang letaknya disebelah luar, tempat penampung kotoran, tempat penampung sisa makanan, dan lampu untuk penerangan pada malam hari.

\section{Bahan Ransum, Amoniasi Urea dan Biofermen- tasi bacteri Lactobacillus complex (BLC) dan te- pung daun sirih (Piper betle L.)}

Bahan ransum yang dipergunakan dalam penelitian ini adalah jagung kunig, kacang kedelai, bungkil kelapa, dedak padi , sekam padi, daun sirih, minyak kelapa, minyak kelapa, $\mathrm{NaCl}$, dan sekam padi teramoniasi serta difermentasi oleh bacteri Lactobacillus complex.

Cara pembuatan sekam padi teramoniasi urea serta dibiofermentasi larutan Effective mikroorganiams-4 (EM-4) (Sudana, 2010).

1. $10 \mathrm{l}$ air dimasukkan $+100 \mathrm{~g}$ urea $+100 \mathrm{ml}$ molaes +100 ml larutan EM-4, kemudian diaduk dengan 
alat pengaduk selama 24 jam dalam keadaan ember tertutup

2. Campur sekam padi dengan larutan hasil amoniasi urea dan larutan EM-4 sampai kepalan sekam padi tidak terurai.

3. Hasil pencampuran sekam padi dengan EM-4 dimasukkan ke dalam karung goni, dimampatkan sampai tidak ada udara di dalam karung goni, kemudian ditutup rapat dan diletakkan pada tempat aman dan tidak kena sinar matahari selama satu minggu.

4. Setelah difermentasi selama satu minggu, campuran sekam padi yang telah difermentasi dikeluarkan dikering udarakan.

Hasil sekam padi yang telah difermentasi larutan EM-4, digunakan untuk campuran pada perlakuan C (ransum mengandung 12,50\% sekam padi yang telah difermentasi), perlakuan $\mathrm{E}$ (ransum mengandung $12,50 \%$ sekam padi yang telah difermentasi dan $1 \%$ daun sirih). Perlakuan A adalah ransum tanpa sekam padi, perlakuan B adalah ransum mengandung 12,50\% tanpa difermentasi, dan perlakuan $\mathrm{D}$ adalah ransum mengandung $12,50 \%$ sekam padi tanpa difermentasi + daun sirih. Larutan EM-4 dan molases diperoleh dari toko pusat pemasaran produk di Yang Batu Denpasar dan daun sirih diperoleh di pasar Desa Pekraman Guwang, Kecamatan Sukawati, Kab. Gianyar.

\section{Komposisi Ransum untuk Penelitian}

Ransum terdiri atas jagung kuning, kacang kedelai, bungkil kelapa, dedak padi, tepung ikan, Mineral B12, Garamdapur ( $\mathrm{NaCl})$, dan sekam padi. Sekam padi ada yang tanpa diolah dan ada yang difermentasi dengan bakteri Lactobacillus complex (BLC) dan disuplementasi dengan tepung daun sirih (Piper betle L) sebagai sumber antioksidan

\section{Rancangan Penelitian}

Rancangan penelitian yang digunakan adalah rancangan acak lengkap (RAL) dengan lima perlakuan yaitu A: ransum tanpa sekam padi dan tanpa daun
Tabel 1. Komposisi bahan penyusuanan ransum itik bali umur12 - 24 minggu

\begin{tabular}{lccccc}
\hline \multicolumn{1}{c}{ Komposisi Bahan } & \multicolumn{5}{c}{ Perlakuan } \\
\cline { 2 - 6 } \multicolumn{1}{c}{ Ransum (\%) } & $\mathrm{A}$ & $\mathrm{B}$ & $\mathrm{C}$ & $\mathrm{D}$ & $\mathrm{E}$ \\
\hline Jagung kuning & 55,36 & 48,34 & 48.34 & 47,34 & 47.34 \\
Kacang kedelai & 9,37 & 12,36 & 1236 & 12,36 & 12,36 \\
Bungkil kelapa & 11,31 & 7,82 & 7,82 & 7,82 & 7,82 \\
Tepung ikan & 10,13 & 10,29 & 10,29 & 10,29 & 10,29 \\
Dedak padi & 13,18 & 5,54 & 5,54 & 5,54 & 5.54 \\
Sekam padi & - & 12,50 & $12,50 *$ & 12,50 & $12,50 *$ \\
Daun sirih & - & - & - & 1,00 & 1,00 \\
Minyak kelapa & - & 2,00 & 2,00 & 2,00 & 2,00 \\
Mineral B12 & 0,50 & 0,50 & 0,50 & 0,50 & 0,50 \\
NaCl & 0,15 & 0,15 & 0,15 & 0,15 & 0,15 \\
Total & 100 & 100 & 100 & 100 & 100 \\
\hline
\end{tabular}

Keterangan

A: ransum tanpa sekam padi dan tanpa daun sirih

B: ransum mengandung $12,50 \%$ sekam padi tanpa fermentasi dan tanpa daun sirih

C: ransum mengandung $12,50 \%$ sekam terfermentasi dan tanpa daun sirih

D: ransum mengandung $12,50 \%$ sekam padi tanpa fermentasi dan daun sirih

E: ransum mengandung $12,50 \%$ sekam padi terfermentasi dan daun sirih

* Terbiofermentasi

sirih, B: ransum mengandung $12,50 \%$ sekam padi tanpa fermentasi dan tanpa daun sirih, C: ransum mengandung $12,50 \%$ sekam terfermentasi dan tanpa daun sirih, D: ransum mengandung 12,50\% sekam padi tanpa fermentasi dan daun sirih, E: ransum mengandung $12,50 \%$ sekam padi terfermentasi dan daun sirih. Setiap perlakuan dengan empat ulangan dan setiap ulangan berisi lima ekor itik bali betina dengan umur tiga minggu dengan bobot badan yang homogen.

\section{Variabel yang Diamati}

Variabel yang diamati dalam penelitian adalah performans meliputi konsumsi ransum, konsumsi antioksidan ransum, bobot badan akhir dan feed conversion rasio (FCR). serta karkas terdiri atas bobot potong, bobot karkas dan persentase karkas.

\section{Analisis Data}

Data yang diperoleh dianalisis dengan sidik ragam dan apabila terdapat perbedaan yang nyata $(\mathrm{P}<0,05)$

Tabel.2. Kandungan nutrisi ransum penelitian

\begin{tabular}{|c|c|c|c|c|c|c|c|}
\hline \multirow{2}{*}{ Kandungan Nutrisi Ransum } & \multirow{2}{*}{ Satuan } & \multicolumn{5}{|c|}{ Perlakuan } & \multirow{2}{*}{$\begin{array}{l}\text { Standard: Scott } \\
\text { et al., (1969) }\end{array}$} \\
\hline & & $A$ & B & $\mathrm{C}$ & $\mathrm{D}$ & $E$ & \\
\hline Metabolisme energi & $\mathrm{Kkal} / \mathrm{kg}$ & 2884,16 & 2859,08 & 2900,00 & 2868.32 & 2865,45 & $2800-2900$ \\
\hline Protein kasar (PK) & $(\%)$ & 17,46 & 17,00 & 17,36 & 17,31 & 17,38 & $15-17$ \\
\hline Lemak kasar (EE) & $(\%)$ & 5,94 & 6,08 & 5,63 & 5,92 & 5,94 & $3-6$ \\
\hline Serat kasar (SK) & $(\%)$ & 4,63 & 8,23 & 7,34 & 8,84 & 7,30 & $6-9$ \\
\hline Calsium (Ca) & $(\%)$ & 0,90 & 0,88 & 0,99 & 0,87 & 0,89 & 0,80 \\
\hline Fosfor tersedia & $(\%)$ & 0,69 & 0,67 & 0,66 & 0,67 & 0,65 & 0,45 \\
\hline $\begin{array}{l}\text { Keterangan: } \\
\text { A: ransum tanpa mengandung sekam } \\
\text { B: ransum mengandung } 12,50 \% \text { seka } \\
\text { C: ransum mengandung } 12,50 \% \text { seka } \\
\text { D: ransum mengandung } 12,50 \% \text { seka } \\
\text { E: ransum mengandung } 12,50 \% \text { seka }\end{array}$ & $\begin{array}{l}\text { dan tanpa o } \\
\text { i tanpa fern } \\
\text { ermentasi c } \\
\text { i tanpa fern } \\
\text { i terfermen }\end{array}$ & $\begin{array}{l}\text { h } \\
\text { dan tanpa } \\
\text { da daun siri } \\
\text { dan daun s } \\
\text { daun sirih }\end{array}$ & & & & & \\
\hline
\end{tabular}


diantara perlakuan dilanjutkan dengan uji Duncan (Steel dan Torrie, 1989)

\section{HASIL DAN PEMBAHASAN}

\section{Pemanfaatan Sekam Padi Terfermentasi Disu- plementasi Daun Sirih (Piper betle L) terhadap Performans Itik Bali Umur 22 Minggu}

\section{Konsumsi Ransum}

Konsumsi ransum pada itik yang mendapatkan ransum kontrol (ransum tanpa sekam padi (perlakuan A) selama 10 minggu adalah 5,222 kg/ekor (Tabel 3). Pemberian perlakuan B (ransum 12,50\% sekam padi tanpa fermentasi) dapat meningkatkan konsumsi ransum sebesar $5.74 \%(\mathrm{P}<0,05)$, sedangkan pemberian ransum $12,50 \%$ sekam padi terfermentasi (perlakuan C), ransum $12,50 \%$ sekam padi dan daun sirih (perlakuanD), serta ransum $12,50 \%$ sekam padi terfermentasi suplementasi daun sirih (perlakuan E) tidak berpengaruh terhadap konsumsi ransum $(\mathrm{P}>0,05)$ dibandingkan dengan perlakuan A. Pemberian 12,50\% sekam padi tanpa fermentasi dapat menurunkan kecernaan, karena kandungan serat kasar yang relatif tinggi pada sekam padi. Fermentasi larutan Effective microorganism-4 (EM-4) dapat meningkatkan nilai nutrisi sekam padi, terutama protein kasar, dari sebelum fermentasi adalah 4,66\% dan setelah difermentasi menjadi $7,49 \%$, sedangkan pada serat kasar terjadi penurunan dari $43,59 \%$ menjadi 21,01\%. Hal ini yang menyebabkan konsumsi ransum pada perlakuan $\mathrm{C}$ dan $\mathrm{E}$ terjadi penurunan konsumsi ransum, walaupun tidak berbeda nyata $(\mathrm{P}>0,05)(\mathrm{Gaga}$ et al., 2018). Hasil penelitian ini sesuai yang diperoleh oleh Susila et al. (2017) bahwa ransum yang mengandung 12,50\% sekam padi difermentasi Aspergillus niger yang disuplementasi daun ubi jalar ungu mengkonsumsi ransum lebih rendah daripada perlakuan kontrol dan lebih rendah daripada perlakuan B (ransum yang mengandung 12,50\% sekam padi tanpa fermentasi). Hal yang sama juga diperoleh Yadnya dan Wirawan (2016) bahwa pemberian sekam padi yang terfermentasi oleh multienzim disuplementasi daun noni (Morinda citrifolia L.) mengkonsumsi ransum yang lebih rendah daripada itik yang diberi perlakuan kontrol dan pemberian ransum dengan 10\% sekam padi tanpa fermentasi.

\section{Konsumsi Antioksidan Ransum}

Konsumsi antioksidan ransum pada itik yang mendapatkan perlakuan A adalah 529,12 ppm/ekor (Tabel 3). Pemberian perlakuan B mengkonsumsi antioksidan lebih tinggi $17,27 \%(\mathrm{P}<0,05)$ daripada perlakuan $\mathrm{A}$, sedangkan dengan perlakuan $\mathrm{C}, \mathrm{D}$, dan E dapat meningkatkan konsumsi antioksidan ransum masing-masing adalah 26,68\%, 25,73\%, dan 86,47\% $(\mathrm{P}<0,05)$ dibandingkan dengan perlakuan A. Banyaknya antioksidan yang dikonsumsi sangat tergantung pada ransum yang dikonsumsi serta banyaknya zat antioksidan yang terkandung dalam ransum yang sangat berpengaruh terhadap kapasitas antioksidan (Ishida et al., 2001). Surya et al. (2008) melaporkan bahwa daun sirih (Piper betle L) mempunyai total fenol dan aktivitas antioksidan cukup tinggi yaitu $1070 \mathrm{mg} / 100 \mathrm{ml}$ dan 97,44\% yang menentukan kapasitas antioksidan.

\section{Bobot badan Akhir}

Bobot badan akhir pada itik A dalah 1330,oo g/ekor (Tabel.3) Pemberian perlakuan B menghasilkan bobot badan akhir yang lebih rendah $(\mathrm{P}<0,05)$, sedangkan dengan perlakuan $\mathrm{C}, \mathrm{D}$, dan $\mathrm{E}$ dapat meningkatkan bobot badan akhir masing-masing adalah 7,85\%, 8,57\%, dan $11,09 \%(\mathrm{P}<0,05)$ daripada pemberian perlakuan $\mathrm{A}$. Akibat fermentasi sekam padi oleh bakteri Lactobacillus complex yang terjadi peningkatan nutrisi sekam padi meningkat (Chandra et al., 2012) serta penambahan daun sirih sebagai bahan ransum mengandung senyawa antioksidan yang dapat meningkatkan kecernaan (Yadnya, 2013), sehingga infiltrasi zat- zat nutrisi yang diserap lebih banyak yang berpengaruh terhadap bobot badan akhir yang lebih baik. Hal ini sesuai dengan hasil penelitian yang diperoleh oleh Susila et al. (2015) bahwa

Tabel 3. Pengaruh sekam padi terfermentasi dalam ransum disuplementasi daun sirih terhadap efisiensi penggunaan rnasum itik bali umur 12 - 22 minggu

\begin{tabular}{|c|c|c|c|c|c|c|}
\hline \multirow{2}{*}{ Peubah } & \multicolumn{5}{|c|}{ Perlakuan ${ }^{1)}$} & \multirow{2}{*}{ SEM ${ }^{3)}$} \\
\hline & A & B & $\mathrm{C}$ & $\mathrm{D}$ & $E$ & \\
\hline Konsumsi ransum (kg/ekor) & $5,222 a$ & $5,522 b$ & $5,215 a$ & $5,283 a$ & $5,182 a^{2)}$ & 1,489 \\
\hline Konsumsi antioksidan (ppm/ekor) & $1230,91 b$ & $1201,06 a$ & $1237,04 b$ & $1299,49 c$ & $1311,04 b$ & 1,491 \\
\hline Bobot badan akhir(g/ekor) & $1377,50 a$ & $1347,50 b$ & $1420,00 c$ & $1430,00 c$ & $1311,04 d$ & 1,491 \\
\hline Pertambahan bobot badan (g/ekor) & $291,25 a$ & $260,75 b$ & $334,75 c$ & $342,50 c$ & $386,25 d$ & 5,712 \\
\hline Feed Conversion Ratio (FCR) & $17,92 a$ & $21,24 b$ & $15,57 c$ & 15,43 & $12,94 d$ & 0,400 \\
\hline
\end{tabular}

Keterangan:

1) A: ransum tanpa mengandung sekam padi dan tanpa daun sirih; B: ransum mengandung $12,50 \%$ sekam padi tanpa fermentasi dan tanpa daun sirih; $C$ : ransum mengandung $12,50 \%$ sekam terfermentasi dan tanpa daun sirih; D: ransum mengandung $12,50 \%$ sekam padi tanpa fermentasi dan daun sirih; $\mathrm{E}$ : ransum mengandung $12,50 \%$ sekam padi terfermentasi dan daun sirih

2) Nilai dengan huruf yang berbeda pada baris yang sama menunjukkan berbeda nyata $(P<0,05)$

3) SEM: Standard Error of the Treatment Means 
pemberian sekam padi terfermentasi Aspergillus niger yang disuplementasi daun ubi jalar ungu (Ipomoea batatas L) dapat meningkatkan bobot badan akhir itik umur 22 minggu.

\section{Pertambahan Bobot Badan}

Pertambahan bobot badan pada itik A adalah 291,25 g/ekor (Tabel 3) Pemberian perlakuan B dapat menurunkan pertambahan bobot badan sebesar 10,47\% $(\mathrm{P}<0,05)$, sedangkan pemberian perlakuan $\mathrm{C}, \mathrm{D}$, dan $\mathrm{E}$ dapat meningkatkan pertambahan bobot badan sebesar 14,93\%, 17,59\%, dan 32,61\% $(\mathrm{P}<0,05)$ daripada perlakuan A. Adanya fermentasi oleh enzim-enzim yang terdapat pada EM-4 dan daun sirih dapat meningkatkan kecernaan, sehingga zat nutrisi yang diserap lebih banyak (Yadnya et al., 2012) dan berpengaruh terhadap pertambahan bobot badan dan bobot badan akhir yang lebih baik daripada itik yang diberikan perlakuan kontrol ( A) (Yadnya et al., 2016).

\section{Feed Conversion Ratio (FCR)}

Feed conversion ratio (FCR) pada itik A adalah 13,78 (Tabel 3). Pemberian perlakuan B dapat meningkatkan FCR ransum sebesar 13,86\% $(\mathrm{P}<0,05)$, sedangkan pemberian perlakuan C, D, dan Edapat menurunkan FCR masing-masing sebesar 21,77\%., 23,29\% dan 28,59\% $(\mathrm{P}>0,05)$ dibandingkan dengan pemberian perlakuan A. Adanya perbedaan yang nyata pada pemberian sekam padi terfermentasi yang disuplementasi daun sirih, karena adanya peningkatan pertambahan bobot badan yang disertai dengan peningkatan bobot badan akhir yang berbepagaruh terhadap hasil FCR yang lebih baik. Yadnya et al. (2016a) melaporkan bahwa pemberian ransum yang difermentasi dengan larutan EM-4 dan dikombinasikan dengan MSG (mono sodium glutamat) dapat berpengaruh terhadap pertambahan bobot badan dan dapat memperbaiki FCR pada itik campble. Hasil penelitian ini sesuai dengan yang diperoleh oleh Susila et al. (2016) bahwa pemberian sekam padi terfermentasi Aspergillus niger disuplementasi daun ubi jalar ungu (Ipomoea batatas L) dapat memperbaiki FCR itik bali umur 22 minggu.

\section{Kajian Pemanfaatan Sekam Padi difermentasi dalam Ransum Disuplementasi Daun Sirih (Piper beetle L) terhadap Karkas Itik Bali Umur 22Minggu}

\section{Bobot Potong}

Bobot potong sesuai dengan bobot badan akhir pada saat itik berumur 22 minggu disajikan pada Tabel 4 .

Bobot karkas pada itik yang mendapatkan perlakuan A adalah 872,98 g/ekor (Tabel 4). Pemberian perlakuan $\mathrm{B}$ tidak berpengaruh terhadap bobot karkas $(\mathrm{P}>0,05)$, sedangkan dengan pemberian perlakuan $\mathrm{C}, \mathrm{D}$, dan E dapat meningkatkan bobot karkas masing-masing adalah 8,98 \% 13,68\%, dan 20,09\% $(\mathrm{P}<0,05)$ berbeda nyata dibandingkan dengan perlakuan $\mathrm{A}$. Bobot karkas sangat tergantung dari bobot potong dan bobot bukan karkas (Soeparno, 2004). Selain tinggi bobot potong ada kecendrungan bobot karkas yang lebih besar. Budiartha (2016) melaporkan pemberian sekam padi terfermentasi Aspergillus niger disuplementasi daun ubi jalar dapat meningkatkan bobot potong dan bobot karkas secara nyata dibandingkan pemberian ransum kontrol. Yadnya et al., (2007) melaporkan pemberian 10\% serbuk gergaji kayu yang terfermentasi larutan EM-4 yang disuplementasi daun salam dapat memperbaiki efisiensi penggunaan ransum, bobot potong dan bobot karkas dibandingkan perlakuan yang lainnya.

\section{Persentase Karkas}

Persentase karkas pada itik adalah 65,62\% (Tabel 4). Pemberian perlakuan $B$ dapat menurunkan persentase karkas sebesar 1,76\% $(\mathrm{P}<0,05)$, sedangkan dengan pemberian perlakuan $\mathrm{C}$ tidak berbeda nyata $(\mathrm{P}>0,05)$, sedangkan dengan pemberian $\mathrm{D}$ dan $\mathrm{E}$ dapat meningkatkan persentase karkas $(\mathrm{P}<0,05)$ daripada perlakuan A. Pemberian daun sirih sebagai sumber antioksidan dapat meningkatkan kecernaaan ransum yang akan berpengaruh terhadap pertambahan bobot badan (Yadnya, 2013) dan berpengaruh terhadap bobot potong dan bobot karkas yang lebih baik. Persentase karkas sangat dipengaruhi oleh bobot potong dan bobot

Tabel 4. Kajian pemanfaatan sekam padi terfermentasi yangdisuplementasi daun sirih (Piper betle L) terhadap karkas itik bali umur 12 - 22 minggu

\begin{tabular}{|c|c|c|c|c|c|c|}
\hline \multirow{2}{*}{ Peubah yang diamati } & \multicolumn{5}{|c|}{ Perlakuan } & \multirow{2}{*}{ SEM } \\
\hline & A & B & C & D & $E$ & \\
\hline Bobot potong (g/ekor) & $1330,0 d$ & $1302,75 e$ & $1434,5 c$ & $1444,0 b$ & $1482,5 a$ & 0,0329 \\
\hline Bobot karkas (g/ekor) & $872,74 d$ & $839,75 e$ & $951,15 c$ & $992,20 b$ & $1048,11 a$ & 3,365 \\
\hline Persentase karkas (\%) & $65,62 d$ & $64,46 \mathrm{e}$ & $66,27 c$ & $68,50 \mathrm{~b}$ & $70,95 a$ & 0,288 \\
\hline
\end{tabular}

Keterangan:

1) A: ransum tanpa mengandung sekam padi dan tanpa daun sirih; B: ransum mengandung $12,50 \%$ sekam padi tanpa fermentasi dan tanpa daun sirih; C: ransum mengandung $12,50 \%$ sekam terfermentasi dan tanpa daun sirih; D: ransum mengandung $12,50 \%$ sekam padi tanpa fermentasi dan daun sirih; E: ransum mengandung $12,50 \%$ sekam padi terfermentasi dan daun sirih

2) Nilai dengan huruf yang berbeda pada baris yang sama menunjukkan berbeda nyata $(P<0,05)$

3) SEM: Standard Error of the Treatment Means 
karkas (Witariadi et al., 2012). Susila et al. (2016) melaporkan pemberian sekam padi terfermentasi yang disuplementasi ubi jalar ungu yang kaya akan antosianin sebagai sumber antioksidan dapat meningkatkan bobot dan dan persentase karkas secara nyata $(\mathrm{P}<0,05)$ dibandingkan dengan pemberian ransum tanpa daun ubi jalar ungu.

\section{SIMPULAN}

Berdasarkan hasil penelitian dapat disimpulkan bahwa pemberian ransum sekam padi difermentasi Effective mikroorganisms-4 (EM-4) di dalam ransum yang disuplementasi daun sirih (Piper betle L.) dapat memperbaiki penampilan dan karkas itik bali umur 22 minggu.

\section{UCAPAN TERIMA KASIH}

Penulis mengucapkan ucapan terima kasih kepada Menteri Riset, Teknoogi dan Pendidikan Tinggi atas bantuan dana yang telah diberikan melalui Dana Hibah Unggulan Perguruan Tinggi melalui Rektor Universitas Udayana/Ketua Lembaga Penelitian dan Pengabdiaan kepada Masyarakat, Universitas Udayana dengan kontrak penelitian Penelitian Unggulan Perguruan Tinggi Tahun Anggaran 2018, Nomor: 171.122/ UN14.4.A/LT/2018, tanggal 19 Februari 2018, sehingga penelitian dapat berjalan dengan semestinya.

\section{DAFTAR PUSTAKA}

Chandra, T., V. G. Kereh., I M. Untu, dan B. W. Rambet. 2013. Pengayaan NNSP berbasis Bioteknologi EM-4 sebagai Bahan Pakan Organik. Jurnal Zootek (Zootek Journal). Vol.32. Nomor 5. p. $158-171$.

Hartawan, I K. B. 2017. Pengaruh Aras Sekam Padi Terfermentasi dalam Ransum Disuplementasi Daun Ubi Jalar Ungu (Ipomoea batatas L.) terhadap Bobot Potong dan Komposisi Fisik Karkas Itik Bali. Skripsi Fakultas Peternakan, Universitas Udayana.

Higa, T dan I G. N. Wididana. 1993. Effective Microorganisms-4 (EM-4) Seri Pertanian Akrab Lingkungan. Jakarta.

Ishida, H., H. Suzuno., N. Sugiyama., S.Innami, T. Tadokoro, A. Maekawa. 2000. Nutritive Evaluation on Chemical Components of Leaves, Stalks and Stems of Sweet Potatoes (Ipomoea batatas Poir). J. Food Chemistry, $68: 359-367$.

Lubis, D. A. 1992. Ilmu Makanan Ternak, PT. Pembanguan, Jakarta.

Matram, R. B. 1984. Pengaruh Imbangan Kalori/Protein dan Pembatasan Ransum terhadap Pertumbuhan dan Produksi Itik Bali. Disertasi. Universitas Padjadjaran
Bandung.

Nitis, I M. 1980. Makanan Ternak Salah satu Sarana Untuk Meningkatkan Produksi Ternak. Orasi Ilmiah Pengukuhan Guru Besar dalam Ilmu Makanan Ternak. Fakultas Peternakan, Universitas Udayana, DenpasarBali.

Steel, R. G. D dan J. M. Torrie. 1989. Priciples and Procedure of statistic. Mc.Graw,Hill,Book Co Inc,New York, London.

Sudana, I. B. 2010. Bahan Ajar Bioteknologi. Program Studi (S3) Ilmu Peternakan, Pasca Sarjana, Fakultas Peternakan, Universitas Udayana.

Surya, Y. S., Catrien, Ertanto, dan Tomi. 2008. http: repository.ipb.ac.id/handle/123456789/33022.

Susila, T. G. O., T. G. B. Yadnya, dan I G. K. Roni. 2015. Upaya Peningkatan Nilai Nutrisi Sekam Padi melalui Amoniasi Urea dan Biofermentasi Aspergillus niger disuplementasi Daun Ubi Jalar Ungu terhadap Penampilan, Kapasitas Antioksidan, dan Kadar Kolesterol Daging Itik Fase Pertumbuhan. Laporan Penelitian Hibah Unggulam Perguruan Tinggi. Fakultas Peternakan, Universitas Udayana.

Susila, T. G. O., T. G. Belawa Yadnya, dan N. G. K. Roni. 2016. Kajian Pemanfaatan sekam Padi Diamoniasi Urea dan Biofermentasi Aspergillus niger disuplementasi Daun Ubi Jalar Ungu (Ipomoea batatas L) terhadap Penampilan, Kapasitas Antioksidan, dan Kadar Kolesterol Daging Itik Bali Fase Pertumbuhan, Laporan Penelitian Hibah Unggulam Perguruan Tinggi, Fakultas Peternakan, Universitas Udayana.

Witariadi, N. M., N. G. K. Roni., D. P. M. A. Candrawati, dan A. A. A. S. Trisnadewi. 2012. Kualitas Karkas Itik Bali Umur 23 Minggu yang Diberikan Ransum Ubi Jalar Ungu (Ipomoea batatas L.) yang Terfermentasi. Laporan Penelitian. Fakultas Peternakan, Universitas Udayana.

Yadnya, T. G. B., I. B. G. Partama, dan A. A. A. S. Trisnadewi. 2012. Pengaruh Ransum Ubi Jalar Ungu (Ipomooea batatas L.) Terfermentasi Aspergillus niger terhadap Kecernaan Ransum, Retensi Protein, dan Pertambahan Bobot Badan Itik Bali. Prosiding Semnas FAI 2012 ISBN: 978-602-18810-0-2, Universitas Mercu Buana, Yogyakarta.

Yadnya, T. G. B., N. M. S. Sukmawati, dan I K. M. Budiasa. 2007. Pengaruh Pemberian Serbuk Gergaji Kayu yang Diamoniasi dan Daun Salam Terfermentasi dalam Ransum terhadap Penampilan, Karkas dan Kadar Kolesterol Darah Itik Bali. Prosiding Seminar Nasional, Fapet, UGM, Yogyakarta, 24 - 27 Juli 2007.

Yadnya,T. G. B. dan I W. Wirawan. 2016. Kajian Pemanfaatan Sekam Padi mengandung Daun Noni (Morinda citrifolia L.) disuplementasi Multienzim terhadap Kapasitas Antioksidan, Produksi Telur dan dan Kualitas Telur itik Bali pada Fase Peneluran Pertama. 
Laporan Penelitian Hibah Unggulan Program Studi. Fakultas Peternakan, Universitas Udayana.

Yadnya,T. G. B., A. A. A. S. Trisnadewi, I K. Sukada, dan I

G. L. Oka. 2016. The Effect of Offered Diet Containing Rice Hull and Mono Sodium Glutamat (MSG) and Effective Microorganism-4 (EM-4) Solution on the Performance of Campblell Duck. International Research Journal of Engineering IT and Scientific Research (IRJEIS), Vol.2 Issue II, November 2016, pages 66 72. ISSN :2454 - 2261, Impact Factor : 3.603 . 